The $5^{\text {th }}$ Conf. of SSFOP “Maximizing utilization of ornamental plants in urban areas

landscaping”, Cairo, Egypt, 24/2/2019

Scientific J. Flowers \& Ornamental Plants

www.ssfop.com/journal

ISSN: 2356-7864

doi: $10.21608 /$ sjfop.2019.31469

\title{
RESPONSE OF CORIANDER VEGETATIVE GROWTH, YIELD COMPONENTS, PIERCING-SUCKING PESTS INFESTATION AND ASSOCIATED NATURAL ENEMIES TO NITROGEN FERTILIZER RATES AND FOLIAR SPRAY WITH L-TRYPTOPHAN, PHENYLALANINE ACIDS UNDER SANDY SOIL CONDITIONS
}

\author{
E.A.M. El-Mogy ${ }^{*}$ K.E. Attia ; Naglaa F.S. Elbohy ${ }^{* *}$ and M.M.A. Ibrahim ${ }^{* *}$ \\ * Medicinal and Aromatic Plants Research Department, Horticulture Research Institute, ARC, Egypt. \\ ** Ornamental Plants and Landscape Gardening Res. Dept., Hort. Res. Inst., ARC, Egypt. \\ Piercing-Sucking Insect Research Department, Plant Protection Research Institute, ARC, Egypt.
}

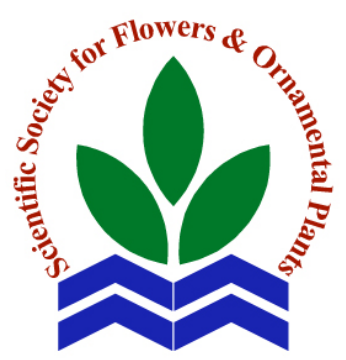

Scientific J. Flowers \& Ornamental Plants, 6(1):21-41 (2019).

Received:

15/1/2019

Accepted:

31/1/2019
ABSTRACT: The present work was conducted at the Experimental Farm of EL-Quassasin Horticultural Research Station, Ismailia Governorate, Egypt, during the two winter consecutive seasons of 2016/2017 and 2017/2018. The aim was, to investigate the effect of different nitrogen fertilization rates (control, 50, 75 and $100 \%$ of recommended $\mathrm{N}$ rate), amino acids type (control, L-tryptophan, phenylalanine and L-tryptophan + phenylalanine) as a foliar spray at $150 \mathrm{mg} / \mathrm{l}$ for each one and their interactions on growth and production of coriander and piercing-sucking pests infestation. The obtained results indicated that, nitrogen fertilization rate at $300 \mathrm{~kg}$ ammonium sulfate/feddan (recommended rate) significantly increased growth parameters (plant height, number of branches/plant and fresh and dry herb weights/plant), root system (fresh and dry weights of roots/plant and root length), yield components (number of umbels/plant and number of florets/umbel/plant, fruit yield/plant and /feddan), volatile oil productivity (volatile oil percentage, volatile oil yield/plant and /feddan) and chemical constituents (N, P, K and total carbohydrates percentages) compared to control. Moreover, the highest values of the above mentioned characters were registered by foliar spray of Ltryptophan + phenylalanine with significant differences between the other rates under study. Generally, the better growth characters and root system, higher yield components and volatile oil production, chemical constituents of fruits could be obtained by spraying Ltryptophan + phenylalanine at $150 \mathrm{mg} / \mathrm{l}$ on fertilized coriander plants with nitrogen at the recommended rate, followed by the combined treatment of nitrogen fertilization as $75 \%$ plus L-tryptophan + phenylalanine. In the same trend, highly significant differences ( $\leq$ 0.05 ) between the mean numbers of the piercing-sucking pests; i.e., Hyadaphis coriandri (Das), Bemisia tabaci (Genn.), Thrips tabaci (Lind.), Tetranychus urticea Koch., and their associated natural enemies i.e., Coccinella spp, Chrisoprella carnea (Steph.), aphids parasitoids and predacious mite which were resulted as the variation in nitrogen fertilization rates, and foliar spray of amino acids types. Also, the simple correlation calculation revealed significant coefficients for the relation between each of the surveyed pests and their associated 
natural enemies correlated with growth parameters (plant height and number of branches/plant) and seed yield/plant.

Key words: Coriander, nitrogen, amino acids, plant growth, yield, volatile oil, chlorophyll.

\section{INTRODUCTION}

Coriander (Coriandrum sativum L.) which belongs to the Family Apiaceae (Umbelliferae) is mainly cultivated from its fruits (Mhemdi et al., 2011). It is an annual, herbaceous plant originated from the Mediterranean and Middle Eastern regions and known as a medicinal plants. It contains an essential oil (0.03 to 2.6\%) (Nadeem et al., 2013). All parts of this herb are in use as flavoring agent and/or as traditional remedies for the treatment of different disorders in the folk medicine systems of different civilizations. Coriander closely resembles flat leaf parsley. The fruits are mainly responsible for the medical use of coriander and have been used as a drug for indigestion, against worms, rheumatism and pain in the joints (Wangensteen et al., 2004) and have been recommended for dyspeptic complaints, loss of appetite, convulsion, insomnia and anxiety (Emamghoreishi et al., 2005).

Nitrogen has many functions in plant life. It is an important constituent of protoplasm enzymes, the biological catalytic agent which speed up life process. Nitrogen is present in chlorophyll phosphatides, alkaloids, glycosides and many other organic substances of plant cell, (Vopyan, 1984).

Amino acids as organic nitrogenous compounds are the building blocks in the synthesis of proteins, (Davies, 1982). Amino acids viz., tryptophan and phenylalanine are particularly important for cell growth stimulation. They act as buffers which help to maintain favorable $\mathrm{pH}$ value within the plant cell, since they contain both acid and basic groups; they decline the ammonia from the cell. The regulatory influence of amino acids on plant growth could be declared by the notion that some amino acids e.g. tryptophan is hydroxyl phenyl amino acid that is used to build neurotransmitters and hormones (Walter and Nawacke, 1978).

Coriander plants are subjected to be attacked by many pests species, which cause a serious damage for vegetative parts, seed quantity and quality. Piercing sucking pests are the most destructive insects on these plants (Butani, 1984; Ali, 1988; Jain and Yadav., 1989; EL-Sayed et al., 1990; ElSayed, 1993; Upadhyay et al., 1996; ELKordy et. al., 1999; Afsah, 2005 and Chaudhary et.al., 2009). Coriander aphid, Hyadaphis coriandri reported to be the main aphid species infesting coriander and causes about 19 per cent of losses (Meena et al., 2011). On the other side, coriander fields may harbor beneficial insects, such as predators, parasitoids, which play a noticeable role in controlling the pests and subsequently improving the production of these plants (Rashad, 1976 and 1978; Hussein and Abd EL-Aal, 1982; AL-Qarni, 2005; Abd EL-Moniem and Abd EL-Wahab, 2006 and Abd-EL-Karim et al., 2011). Also, many entomologists reported that there is strong relationship between the levels of nitrogen fertilization, amino acids and the levels of piercing-sucking pests infestation, which followed by the appearance of their predators and parasitoids.

Therefore, the aim of this research is to determine the effects of nitrogen fertilization rates as well as foliar spray application of Ltryptophan and phenylalanine on coriander, especially on growth parameters, yield components and chemical constituents as well as volatile oil productivity, under Ismailia Governorate conditions. 


\section{MATERIALS AND METHODS}

The present study was carried out at the Experimental Farm of EL-Quassasin Horticultural Research Station, Ismailia Governorate, Egypt during the two winter consecutive seasons of 2016/2017 and 2017/2018. Seeds of coriander (Coriandrum sativum L.) were obtained from Medicinal and Aromatic Plants Research Dept., Hort. Res. Inst., ARC, Dokky, Giza. Seeds of coriander were sown on $16^{\text {th }}$ and $15^{\text {th }}$ of October during $1^{\text {st }}$ and $2^{\text {nd }}$ seasons, respectively, and immediately irrigated. After three weeks from planting, seedlings were thinned to be two plants/hill. The physical and chemical properties of the used experimental soil are shown in Table a, according to Chapman and Pratt (1978).

The plot area was $10.8 \mathrm{~m}^{2}(1.80 \times 6.00$ $\mathrm{m})$ included three rows under drip irrigation system. Each row was $60 \mathrm{~cm}$ wide and six meters in length. The seeds were sown in hills on one side of the row, and hills were spaced $30 \mathrm{~cm}$, a part.

Treatments, four rates of nitrogen fertilization (control, 50, 75 and 100\% of recommended rate), four types of amino acids (control, L-tryptophan, phenylalanine and L-tryptophan + phenylalanine) as foliar spray at $150 \mathrm{mg} / \mathrm{l}$ for each one beside their interaction treatments to consist sixteen treatments in this experiment. Recommended rate of nitrogen fertilization was $300 \mathrm{~kg}$ of ammonium sulfate $(20.5 \% \mathrm{~N})$ per feddan. Nitrogen rates were divided into five deses as fertigation. The amino acid treatments were applied as foliar application at 21, 42 and 63 days after sowing. Each experimental unit received two liters solution using spreading agent (Super Film at a rate of $1 \mathrm{ml}$ $\mathrm{l}^{-1}$ ), also, the untreated control plants were sprayed with tap water. The sixteen treatments were arranged as a split-plot experiment in randomized complete block design with three replications
All treatments were fertilized with 200 kg ordinary superphosphate $\left(15.5 \% \mathrm{P}_{2} \mathrm{O}_{5}\right)$ and $50 \mathrm{~kg}$ potassium sulfate $\left(50 \% \mathrm{~K}_{2} \mathrm{O}\right)$. Phosphorus fertilizer was applied during soil preparation. Nitrogen and potassium fertilizers were divided into five equal doses and were added to the soil through the irrigation system starting from 21 days after sowing and every 10 days later. Also, all normal agricultural practices of growing coriander plants were done whenever needed and no pesticides were applied during the study periods.

\section{Recorded data:}

\section{Growth parameters:}

Plant height (cm), number of branches/plant and fresh and dry weights of herb/plant were determined. Also, root system of coriander plant, i.e., fresh and dry weights of roots/plant (g) and root length $(\mathrm{cm})$ of the longest root were recorded.

\section{Yield components:}

At harvest stage (about 120 days after planting), number of umbels/plant, number of florets/umbel/plant as well as fruit yield/plant (g) and/faddan (kg) were determined.

\section{Volatile oil production:}

The volatile oil from air-dried fruits of coriander plants was isolated by hydro distillation for $3 \mathrm{hr}$., in order to extract the volatile oils according to Guenther (1961) and the volatile oil yield per coriander plant (ml) and per faddan (L) were calculated.

\section{Chemical constituents:}

At the harvest time, coriander fruits were air dried and $\mathrm{N}, \mathrm{P}$ and $\mathrm{K}$ contents were measured according to A.O.A.C. (1990). Also, total carbohydrates percentage in fruits was determined according to the method described by Dubois et al. (1956). 
Table a. Physical and chemical properties of the experimental soil.

\begin{tabular}{|c|c|c|c|c|c|c|c|c|c|c|c|c|}
\hline & (\%) & $\begin{array}{c}\text { Silt (\%) } \\
9.26 \\
\end{array}$ & & $\begin{array}{l}\text { Physic } \\
\text { Fine }\end{array}$ & $\begin{array}{l}\text { malys } \\
\text { d (\%) } \\
2\end{array}$ & & & $\begin{array}{r}\text { Coarse st } \\
5.7\end{array}$ & (\%) & \multicolumn{3}{|c|}{ Texture class } \\
\hline \multicolumn{13}{|c|}{ Chemical analysis } \\
\hline \multirow{2}{*}{ pH } & \multirow{2}{*}{$\begin{array}{c}\text { EC } \\
\text { mmohs } \\
/ \mathbf{c m}\end{array}$} & \multirow{2}{*}{$\begin{array}{c}\text { Organic } \\
\text { matter } \\
\mathbf{g ~ k g}^{-1}\end{array}$} & \multicolumn{4}{|c|}{ Soluble cations (meq. $\mathrm{L}^{-1}$ ) } & \multicolumn{3}{|c|}{ Soluble anions (meq. $\mathrm{L}^{-1}$ ) } & \multicolumn{3}{|c|}{$\begin{array}{l}\text { Available } \\
\left(\mathrm{mg} \mathrm{kg}^{-1}\right)\end{array}$} \\
\hline & & & $\mathrm{Mg}^{+2}$ & $\mathrm{Ca}^{+2}$ & $\mathrm{~K}^{+}$ & $\mathrm{Na}^{+}$ & $\mathrm{Cl}^{-}$ & $\mathrm{HCO}_{3}^{-}$ & $\mathrm{SO}_{4}^{-2}$ & $\mathbf{N}$ & $\mathbf{P}$ & $\mathbf{K}$ \\
\hline 8.12 & 0.96 & 0.36 & 2.65 & 3.61 & 0.67 & 1.81 & 4.25 & 1.67 & 3.05 & 25 & 12 & 190 \\
\hline
\end{tabular}

Insect, mite pests and associated natural enemies:

Weekly samples of ten seedlings or ten infested branches of mature plants in each replicate plot were selected randomly and inspected actually early in the morning in the field using hand lens (10x), to count individuals of all stages of pests and associated predators, while the aphids parasitoids were counted as aphids mummies in all treated plots as well as control one. The mean numbers of pests and associated natural enemies were estimated based on the branches number/plant and pest or natural enemy's numbers/branch. The sampling operation was started after three weeks of sowing date and continued till harvest.

\section{Statistical analysis:}

The complete randomized block design (CRBD) in a split-plot design was used in this experiment with three replicates. Four nitrogen fertilization rates were randomly arranged in the main plots and four amino acids type were distributed randomly in the sub plots. The obtained data were statistically analyzed and the means were compared using least significant difference (L.S.D) at 5\% level as reported by Gomez and Gomez (1984). The means were compared using computer program of Statistics version 9 (Analytical Software, 2008).

\section{RESULTS AND DISCUSSION}

\section{Growth parameters: Effect of nitrogen fertilization rates:}

Results recorded in Tables (1 and 2) show that coriander growth parameters were gradually increased by increasing nitrogen rates from 50 to $75 \%$ of the recommended rate in the first and second seasons. In addition, the highest values of coriander plant height was obtained from nitrogen rate at $75 \%$ from the recommended rate, and number of branches per plant and fresh and dry weights of herb per plant resulted from the treatment of $100 \%$ compared to control and the other rates under study. This increase was significantly in both seasons in most cases. However, Ahmed and El-Azim (2009) reported that rising nitrogen fertilizer levels from 0 to $40 \mathrm{~kg} /$ fad. significantly increased plant height, fresh and dry weights/plant of Ochradenus baccatus.

Moreover, root system parameters recorded the highest values with nitrogen rate at $100 \%$ (recommended rate) which were significant compared with control in both seasons (Table, 3). In addition, coriander fresh and dry weights of roots per plant and root length were gradually increased by increasing nitrogen rates from 50 to $100 \%$ of the recommended rate in the two seasons. In addition, Abdel-Motagally and Attia (2009) reported that with the application of fertilizers, the roots fresh and dry weights significantly increased with increasing $\mathrm{N}$ fertilizer rates over two seasons of sugar beet plants. Also, Albayrak and Yuksel (2010) demonstrated that nitrogen applications increased root diameter and root length of fodder beet.

However, the increase in plant growth and root system due to the application of nitrogen fertilization might be attributed to its importance to consist the amino acids to form the protein which participate in cell enlargement and cell division as explained by Devlin (1979). 
Table 1. Effect of nitrogen fertilization rates $(\mathrm{N})$, amino acids type (A) and their interaction $(\mathrm{N} \times \mathrm{A})$ treatments on plant height $(\mathrm{cm})$ and number of branches/plant of coriander during 2016/2017 and 2017/2018 seasons.

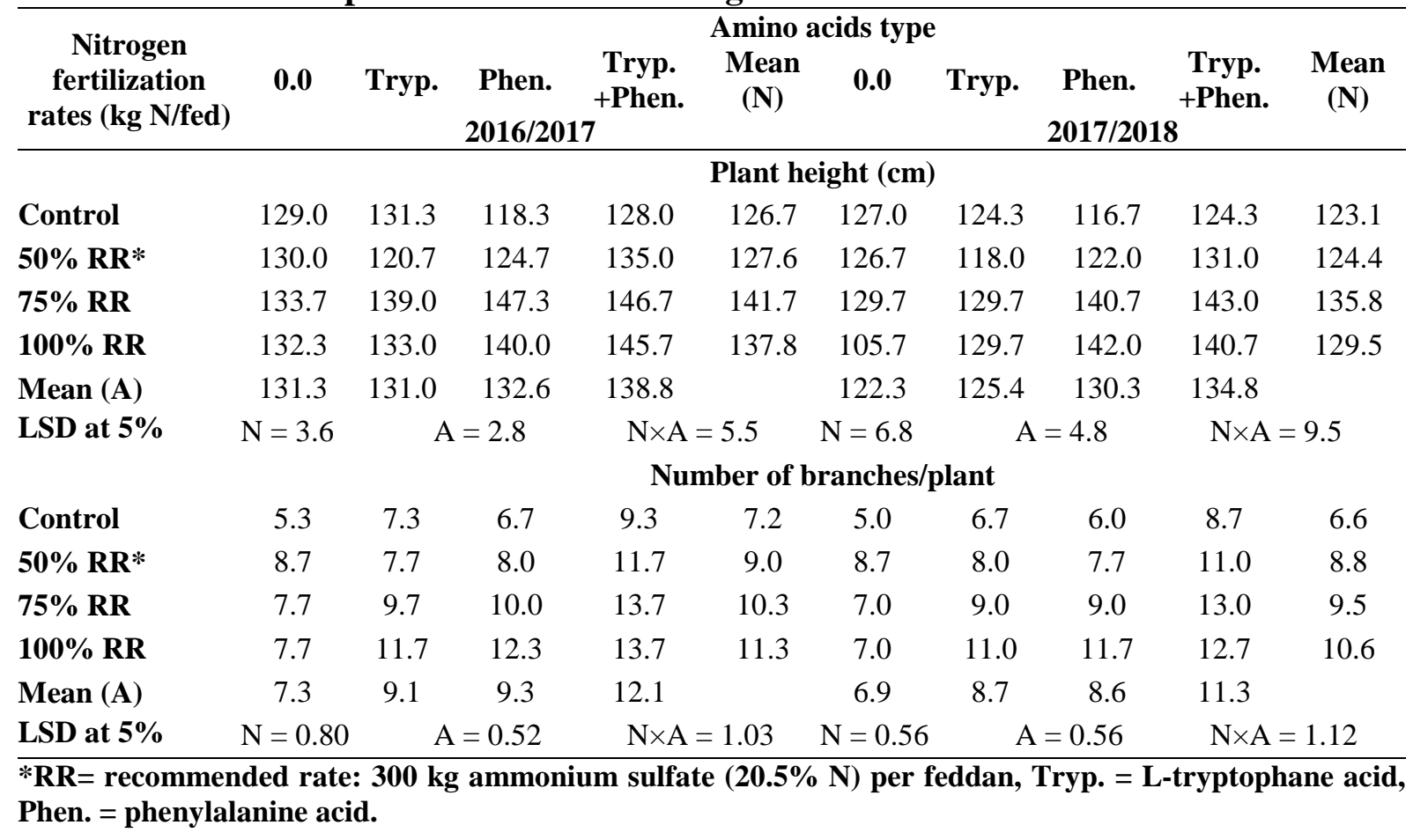

Table 2. Effect of nitrogen fertilization rates $(\mathrm{N})$, amino acids type (A) and their interaction $(\mathrm{N} \times \mathrm{A})$ treatments on fresh and dry weights of herb/plant $(\mathrm{g})$ of coriander plant during 2016/2017 and 2017/2018 seasons.

\begin{tabular}{|c|c|c|c|c|c|c|c|c|c|c|}
\hline \multirow{3}{*}{$\begin{array}{c}\text { Nitrogen } \\
\text { fertilization } \\
\text { rates (kg N/fed) }\end{array}$} & \multicolumn{10}{|c|}{ Amino acids type } \\
\hline & 0.0 & Tryp. & Phen. & $\begin{array}{l}\text { Tryp. } \\
\text { +Phen. }\end{array}$ & $\begin{array}{c}\text { Mean } \\
\text { (N) }\end{array}$ & 0.0 & Tryp. & Phen. & $\begin{array}{l}\text { Tryp. } \\
\text { +Phen. }\end{array}$ & $\begin{array}{c}\text { Mean } \\
\text { (N) }\end{array}$ \\
\hline & \multicolumn{7}{|c|}{ 2016/2017 } & \multicolumn{3}{|c|}{$2017 / 2018$} \\
\hline & \multicolumn{10}{|c|}{ Fresh weight of herb (g)/plant } \\
\hline Control & 62.5 & 161.9 & 122.7 & 107.3 & 113.6 & 54.7 & 107.3 & 106.9 & 91.1 & 90.0 \\
\hline $50 \%$ RR* & 122.9 & 142.7 & 169.1 & 158.7 & 148.4 & 90.9 & 126.9 & 130.5 & 130.1 & 119.6 \\
\hline $75 \%$ RR & 88.6 & 194.9 & 159.6 & 360.4 & 200.9 & 82.9 & 145.8 & 126.7 & 314.8 & 167.5 \\
\hline $100 \%$ RR & 100.3 & 298.4 & 273.7 & 379.3 & 262.9 & 83.7 & 245.0 & 231.0 & 300.5 & 215.1 \\
\hline Mean (A) & 93.6 & 199.5 & 181.3 & 251.4 & & 78.1 & 156.3 & 148.8 & 209.1 & \\
\hline \multirow[t]{2}{*}{ LSD at $5 \%$} & $\mathrm{~N}=48.9$ & \multicolumn{2}{|c|}{$A=37.6$} & \multicolumn{2}{|c|}{$\mathrm{N} \times \mathrm{A}=75.3$} & $\mathrm{~N}=37.2$ & \multicolumn{2}{|c|}{$\mathrm{A}=24.4$} & \multicolumn{2}{|c|}{$\mathrm{N} \times \mathrm{A}=48.7$} \\
\hline & \multicolumn{10}{|c|}{ Dry weight of herb (g)/plant } \\
\hline Control & 14.3 & 14.9 & 24.8 & 19.0 & 18.3 & 12.2 & 10.2 & 18.2 & 17.0 & 14.4 \\
\hline $50 \% \mathrm{RR}^{*}$ & 21.7 & 22.7 & 21.4 & 27.5 & 23.4 & 14.4 & 19.3 & 19.5 & 25.0 & 19.5 \\
\hline $75 \%$ RR & 14.8 & 35.5 & 26.8 & 40.9 & 29.5 & 13.8 & 26.8 & 19.4 & 36.9 & 24.2 \\
\hline $100 \%$ RR & 21.1 & 31.9 & 33.1 & 41.7 & 32.0 & 17.1 & 29.3 & 29.5 & 37.3 & 28.3 \\
\hline Mean (A) & 18.0 & 26.3 & 26.5 & 32.3 & & 14.4 & 21.4 & 21.7 & 29.1 & \\
\hline LSD at $5 \%$ & $\mathrm{~N}=1.93$ & & $=3.46$ & $\mathrm{~N} \times \mathrm{A}$ & 6.92 & $\mathrm{~N}=4.12$ & & $=3.01$ & $\mathrm{~N} \times \mathrm{A}$ & 6.02 \\
\hline
\end{tabular}

* $\mathrm{RR}=$ recommended rate: $300 \mathrm{~kg}$ ammonium sulfate $(20.5 \% \mathrm{~N})$ per feddan, Tryp. = L-tryptophane acid, Phen. $=$ phenylalanine acid. 
Table 3. Effect of nitrogen fertilization rates $(\mathrm{N})$, amino acids type (A) and their interaction $(\mathrm{N} \times \mathrm{A})$ treatments on root system parameters of coriander plant during 2016/2017 and 2017/2018 seasons.

\begin{tabular}{|c|c|c|c|c|c|c|c|c|c|c|}
\hline \multirow{2}{*}{$\begin{array}{c}\text { Nitrogen } \\
\text { fertilization } \\
\text { rates }(\mathrm{kg} \mathrm{N} / \mathrm{fed})\end{array}$} & \multicolumn{10}{|c|}{ Amino acids type } \\
\hline & 0.0 & Tryp. & $\begin{array}{l}\text { Phen. } \\
\text { 2016/201 }\end{array}$ & $\begin{array}{l}\text { Tryp. } \\
+ \text { Phen. } \\
7\end{array}$ & $\begin{array}{c}\text { Mean } \\
\text { (N) }\end{array}$ & 0.0 & Tryp. & $\begin{array}{l}\text { Phen. } \\
\text { 2017/201 }\end{array}$ & $\begin{array}{l}\text { Tryp. } \\
+ \text { Phen. } \\
8\end{array}$ & $\begin{array}{c}\text { Mean } \\
\text { (N) }\end{array}$ \\
\hline & \multicolumn{10}{|c|}{ Fresh weight of root (g)/plant } \\
\hline Control & 2.4 & 5.1 & 5.7 & 5.0 & 4.6 & 2.1 & 4.5 & 4.8 & 4.5 & 4.0 \\
\hline $50 \%$ RR* & 3.7 & 5.4 & 7.9 & 5.9 & 5.7 & 3.4 & 4.9 & 6.5 & 4.9 & 4.9 \\
\hline $75 \%$ RR & 3.9 & 6.0 & 5.2 & 10.5 & 6.4 & 2.8 & 5.4 & 4.7 & 8.5 & 5.4 \\
\hline $100 \%$ RR & 3.7 & 12.2 & 13.8 & 12.7 & 10.6 & 2.9 & 10.5 & 8.8 & 10.0 & 8.1 \\
\hline Mean (A) & 3.4 & 7.2 & 8.2 & 8.5 & & 2.8 & 6.3 & 6.2 & 7.0 & \\
\hline \multirow[t]{2}{*}{ LSD at $5 \%$} & $\mathrm{~N}=2.39$ & \multicolumn{2}{|c|}{$\mathrm{A}=1.35$} & \multicolumn{2}{|c|}{$\mathrm{N} \times \mathrm{A}=2.70$} & $\mathrm{~N}=1.34$ & \multicolumn{2}{|c|}{$\mathrm{A}=1.08$} & \multicolumn{2}{|c|}{$\mathrm{N} \times \mathrm{A}=2.15$} \\
\hline & \multicolumn{10}{|c|}{ Dry weight of root (g)/plant } \\
\hline Control & 0.9 & 1.8 & 1.9 & 1.6 & 1.6 & 0.7 & 1.6 & 1.6 & 1.3 & 1.3 \\
\hline $50 \% R^{*}$ & 1.0 & 2.8 & 1.8 & 1.8 & 1.9 & 1.1 & 1.9 & 1.4 & 1.6 & 1.5 \\
\hline $75 \%$ RR & 1.6 & 2.1 & 1.1 & 2.3 & 1.8 & 1.5 & 1.7 & 1.2 & 1.9 & 1.6 \\
\hline $100 \%$ RR & 1.7 & 2.3 & 3.7 & 3.3 & 2.7 & 1.4 & 1.9 & 2.7 & 2.3 & 2.1 \\
\hline Mean (A) & 1.3 & 2.2 & 2.1 & 2.3 & & 1.2 & 1.8 & 1.7 & 1.8 & \\
\hline \multirow[t]{2}{*}{ LSD at $5 \%$} & $\mathrm{~N}=0.86$ & \multicolumn{2}{|c|}{$\mathrm{A}=0.52$} & \multicolumn{2}{|c|}{$\mathrm{N} \times \mathrm{A}=1.04$} & $\mathrm{~N}=0.29$ & \multicolumn{2}{|c|}{$\mathrm{A}=0.44$} & \multicolumn{2}{|c|}{$\mathrm{N} \times \mathrm{A}=0.89$} \\
\hline & \multicolumn{10}{|c|}{ Root length (cm) } \\
\hline Control & 10.0 & 13.3 & 15.0 & 18.7 & 14.3 & 9.3 & 12.0 & 14.3 & 17.0 & 13.2 \\
\hline $50 \% R^{*}$ & 15.7 & 12.7 & 16.0 & 17.0 & 15.3 & 14.0 & 12.0 & 15.0 & 15.7 & 14.2 \\
\hline $75 \%$ RR & 12.3 & 15.0 & 14.3 & 26.7 & 17.1 & 11.0 & 14.0 & 12.7 & 26.0 & 15.9 \\
\hline $100 \%$ RR & 12.7 & 21.0 & 20.7 & 21.7 & 19.0 & 12.0 & 19.7 & 20.0 & 20.7 & 18.1 \\
\hline Mean (A) & 12.7 & 15.5 & 16.5 & 21.0 & & 11.6 & 14.4 & 15.5 & 19.8 & \\
\hline LSD at $5 \%$ & $\mathrm{~N}=1.10$ & \multicolumn{2}{|c|}{$A=0.73$} & \multicolumn{2}{|c|}{$\mathrm{N} \times \mathrm{A}=1.45$} & $\mathrm{~N}=0.78$ & \multicolumn{2}{|c|}{$A=0.78$} & \multicolumn{2}{|c|}{$\mathrm{N} \times \mathrm{A}=1.55$} \\
\hline
\end{tabular}

\section{Effect of amino acids type:}

Data presented in Tables (1, 2 and 3) reveal that growth and root system parameters were significantly increased by using all treatments of amino acids type compared to control in the two seasons. Furthermore, the highest values of coriander plant height, number of branches per plant and fresh and dry weights of herb per plant as well as fresh and dry weights of roots per plant and root length were obtained from the treatment of combination between Ltryptophan and phenylalanine compared to control and the other ones treatments study. The positive influence of amino acids on growth was shown by Goss (1973) who stated that it can serve as a source of energy and carbon when carbohydrates become deficient in the plant's releasing the ammonia and organic acid form which the amino acid was originally formed as reflected on enhancement of plant growth. The results are in harmony with those found by Gendy and Nosir (2016) who indicated that the application with phenylalanine and L-tryptophan to roselle plant significantly improved the studied plant growth characters such as plant height (cm), number of branches per plant and total plant dry weight (g) in both seasons, compared to untreated plants.

\section{Effect of interaction between nitrogen fertilization and amino acids:}

Results under discussion in Tables (1, 2 and 3) indicate that under amino acid types increasing nitrogen fertilization rates 
gradually increased plant growth and root system parameters, in most cases, during both seasons. However, the highest values in most of abovementioned parameters were achieved by the interaction treatment of 75 and $100 \%$ of recommended rate and Ltryptophan plus phenylalanine compared to control and the other treatments under study. Moreover, EL-Zefzafy et al. (2016) demonstrated that foliar application of either amino acids (tryptophan and phenylalanine) significantly enhanced the growth of Artemisia abrotanum (plant height, number of branches, fresh and dry biomass). Allahdadi and Farzane (2018) showed that, nitrogen application in higher rates improved the growth of artichoke. The highest leaf length, number of leaves per plant, plant fresh and dry weights were observed in 200 kg $\mathrm{N} \mathrm{ha}^{-1}$.

\section{Yield components:}

\section{Effect of nitrogen fertilization rates:}

As for, the effect of nitrogen fertilization on yield components of coriander, it was clear from Table (4) that the different nitrogen rates significantly affected number of umbels/plant and florets/umbel/plant as well as fruit yield per plant and per feddan. The results showed significant differences among nitrogen rates in both seasons. The maximum values in this regard were recorded as a result of 75 and 100\% of recommended rate without any significant differences between them whereas the lowest values were recorded from control, in most cases.

In this regard, Marschner (1995) mentioned that, it was clear that nitrogen treatment increased seeds production, through the development of aerial parts over roots and consequently promoting flowering and fruiting of many crops. The advantages of increasing nitrogen fertilization on enhancing plant growth and yield was previously reported by Ezz El-Din et al. (2010) and Allahdadi and Farzane (2018).

\section{Effect of amino acids type:}

The effects of different amino acid types on the yield components of coriander plant are presented in Table (4). The results show that, L-tryptophan+phenylalanine caused a significant increase in yield component such as number of umbels/plant and No. of florets/umbel/plant and fruit yield per plant and per feddan compared to other treatments and control. In most cases, the above mentioned parameters of coriander yield components showed positive response to the different foliar applications with amino acids during the two seasons. Moreover, there have been reports that foliar application of tryptophan and phenylalanine enhanced the yield and its components (Abou Dahab and Abd El-Aziz, 2006 on Philodendron erubescens and EL-Zefzafy et al., 2016 on Artemisia abrotanum).

\section{Effect of the interaction between nitrogen fertilization and amino acids:}

Regarding the effect of interaction, data presented in Table (4) show that, the interaction between nitrogen fertilization rate and amino acid type had significant effect on number of umbels/plant, No. of florets/umbel/plant, fruit yield per plant and per feddan of coriander, in the two seasons. The interaction between the highest nitrogen rates (75 and 100\% recommended rate) and the two amino acids (L-tryptophan + phenylalanine) recorded the highest values in this connection in most cases without significant difference between both treatments. Furthermore, the combined treatment of $100 \%$ recommended rate of nitrogen plus L-tryptophan + phenylalanine raised the fruit yield per plant over the combined treatment of $75 \%$ recommended rate of nitrogen plus L-tryptophan + phenylalanine by 2.6 and $3.7 \%$ during the two seasons, respectively. In the other way, the combined treatment of $75 \%$ recommended rate of nitrogen plus Ltryptophan + phenylalanine raised the fruit yield per plant over the control by 54.9 and $53.2 \%$ and over $100 \%$ only treatment by 26.4 and $20.3 \%$ in the two seasons, respectively. 
Table 4. Effect of nitrogen fertilization rates $(\mathrm{N})$, amino acids type (A) and their interaction $(\mathrm{N} \times \mathrm{A})$ treatments on yield components of coriander plant during 2016/2017 and 2017/2018 seasons.

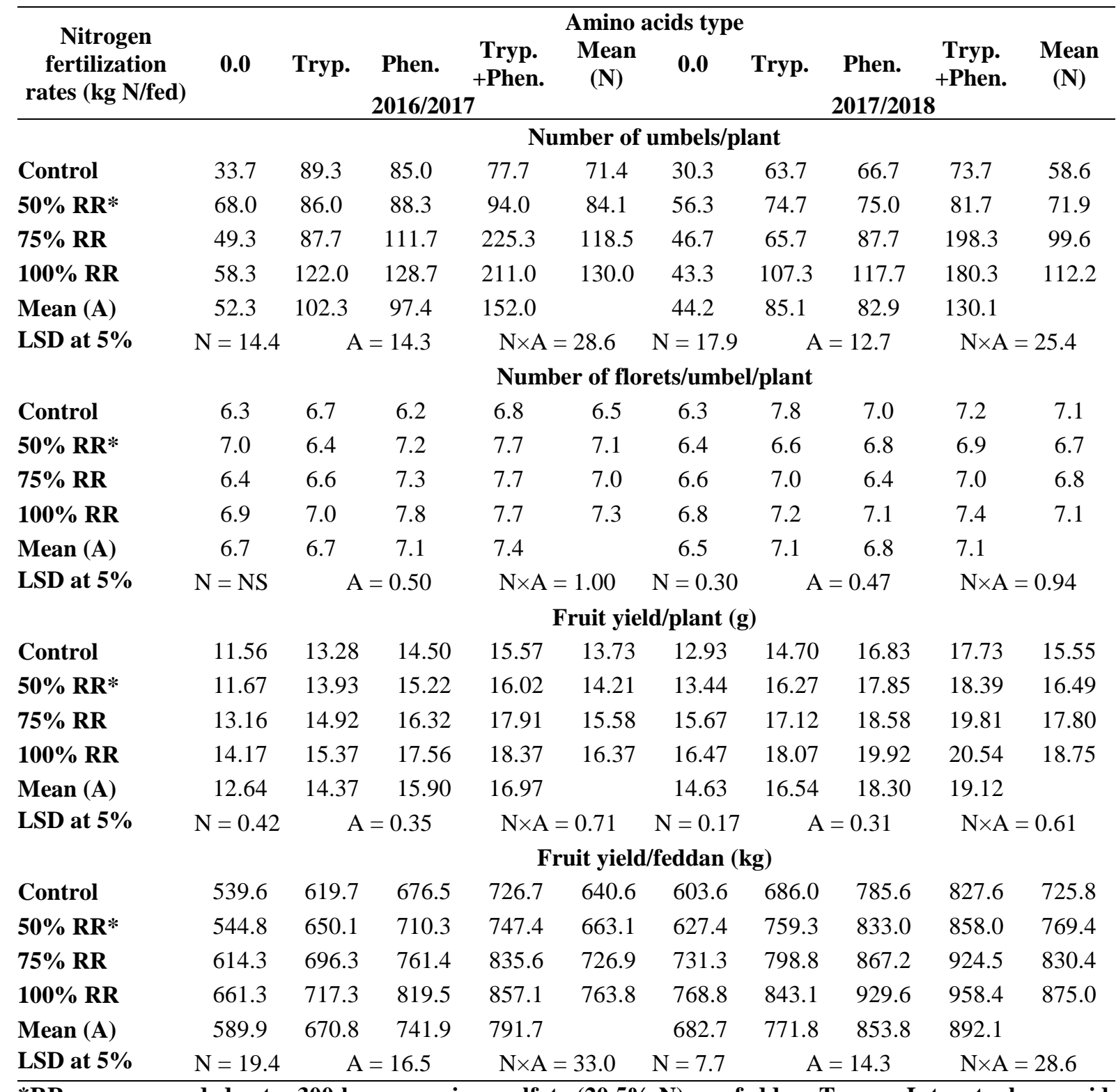

*RR= recommended rate: $300 \mathrm{~kg}$ ammonium sulfate $(20.5 \% \mathrm{~N})$ per feddan, Tryp. $=$ L-tryptophane acid, Phen. $=$ phenylalanine acid.

Moreover, as mentioned above, both nitrogen fertilization rate and amino acid treatments (each alone) increased yield components of coriander plant, in turn, they together might maximize their effects leading to higher fruit yield per feddan.

\section{Volatile oil yield:}

\section{Effect of nitrogen fertilization rates:}

Results in Table (5) show that, the maximum increase in volatile oil percentage and volatile oil yield per plant and per feddan of coriander plant was obtained from the treatment of $100 \%$ recommended rate (300 kg ammonium sulfate per faddan) followed by the treatment of $75 \%$ compared with the other treatments under study. Such increase was significant in the two seasons. Also, volatile oil production of coriander was gradually increased with increasing nitrogen fertilization rates. Furthermore, all nitrogen fertilization treatments significantly increased the abovementioned parameters compared with control [N (0 rate)]. 
Table 5. Effect of nitrogen fertilization rates (N), amino acids type (A) and their interaction $(\mathrm{N} \times \mathrm{A})$ treatments on volatile oil production of coriander plant during $2016 / 2017$ and $2017 / 2018$ seasons.

\begin{tabular}{|c|c|c|c|c|c|c|c|c|c|c|}
\hline \multirow[b]{2}{*}{$\begin{array}{c}\text { Nitrogen } \\
\text { fertilization } \\
\text { rates }(\mathrm{kg} \mathrm{N} / \mathrm{fed})\end{array}$} & \multicolumn{10}{|c|}{ Amino acids type } \\
\hline & 0.0 & Tryp. & $\begin{array}{l}\text { Phen. } \\
\text { 2016/201 }\end{array}$ & $\begin{array}{l}\text { Tryp. } \\
+ \text { Phen. } \\
7\end{array}$ & $\begin{array}{c}\text { Mean } \\
\text { (N) }\end{array}$ & 0.0 & Tryp. & $\begin{array}{l}\text { Phen. } \\
\text { 2017/2018 }\end{array}$ & $\begin{array}{l}\text { Tryp. } \\
+ \text { Phen. } \\
8\end{array}$ & $\begin{array}{c}\text { Mean } \\
\text { (N) }\end{array}$ \\
\hline & \multicolumn{6}{|c|}{ 2016/2017 } & & & & \\
\hline Control & 0.540 & 0.560 & 0.573 & 0.607 & 0.570 & 0.547 & 0.553 & 0.573 & 0.607 & 0.570 \\
\hline $50 \% R^{*}$ & 0.563 & 0.590 & 0.630 & 0.640 & 0.606 & 0.560 & 0.593 & 0.630 & 0.660 & 0.611 \\
\hline $75 \%$ RR & 0.570 & 0.617 & 0.640 & 0.650 & 0.619 & 0.597 & 0.610 & 0.643 & 0.677 & 0.632 \\
\hline $100 \%$ RR & 0.597 & 0.640 & 0.667 & 0.700 & 0.651 & 0.593 & 0.643 & 0.673 & 0.690 & 0.650 \\
\hline Mean (A) & 0.567 & 0.602 & 0.627 & 0.649 & & 0.574 & 0.600 & 0.630 & 0.658 & \\
\hline \multirow[t]{2}{*}{ LSD at $5 \%$} & \multirow[t]{2}{*}{$\mathrm{N}=0.010$} & \multirow{2}{*}{\multicolumn{2}{|c|}{$A=0.008$}} & \multicolumn{2}{|c|}{$\mathrm{N} \times \mathrm{A}=0.017$} & $\mathrm{~N}=0.008$ & \multicolumn{2}{|c|}{$A=0.007$} & \multicolumn{2}{|c|}{$\mathrm{N} \times \mathrm{A}=0.014$} \\
\hline & & & & \multicolumn{7}{|c|}{ Volatile oil yield/plant (ml) } \\
\hline Control & 0.063 & 0.074 & 0.083 & 0.095 & 0.079 & 0.070 & 0.081 & 0.096 & 0.108 & 0.089 \\
\hline $50 \% R^{*}$ & 0.066 & 0.082 & 0.096 & 0.102 & 0.087 & 0.075 & 0.097 & 0.112 & 0.121 & 0.101 \\
\hline $75 \%$ RR & 0.075 & 0.092 & 0.105 & 0.116 & 0.097 & 0.093 & 0.104 & 0.119 & 0.134 & 0.113 \\
\hline $100 \%$ RR & 0.085 & 0.098 & 0.117 & 0.129 & 0.107 & 0.098 & 0.116 & 0.134 & 0.142 & 0.122 \\
\hline Mean (A) & 0.072 & 0.087 & 0.100 & 0.110 & & 0.084 & 0.100 & 0.116 & 0.126 & \\
\hline \multirow[t]{2}{*}{ LSD at $5 \%$} & \multirow[t]{2}{*}{$\mathrm{N}=0.014$} & \multirow{2}{*}{\multicolumn{2}{|c|}{$A=0.012$}} & \multicolumn{2}{|c|}{$\mathrm{N} \times \mathrm{A}=0.024$} & $\mathrm{~N}=0.008$ & \multicolumn{2}{|c|}{$A=0.003$} & \multicolumn{2}{|c|}{$\mathrm{N} \times \mathrm{A}=0.007$} \\
\hline & & & & \multicolumn{7}{|c|}{ Volatile oil yield/feddan (L) } \\
\hline Control & 2.92 & 3.47 & 3.88 & 4.41 & 3.67 & 3.30 & 3.79 & 4.50 & 5.02 & 4.15 \\
\hline $50 \% R^{*}$ & 3.07 & 3.84 & 4.48 & 4.78 & 4.04 & 3.51 & 4.51 & 5.25 & 5.66 & 4.73 \\
\hline $75 \%$ RR & 3.50 & 4.29 & 4.88 & 5.43 & 4.53 & 4.36 & 4.87 & 5.58 & 6.26 & 5.27 \\
\hline $100 \%$ RR & 3.95 & 4.59 & 5.46 & 6.00 & 5.00 & 4.56 & 5.42 & 6.26 & 6.61 & 5.71 \\
\hline Mean (A) & 3.36 & 4.05 & 4.67 & 5.16 & & 3.93 & 4.65 & 5.40 & 5.89 & \\
\hline LSD at $5 \%$ & $\mathrm{~N}=0.14$ & \multicolumn{2}{|c|}{$\mathrm{A}=0.12$} & \multicolumn{2}{|c|}{$\mathrm{N} \times \mathrm{A}=0.23$} & $\mathrm{~N}=0.11$ & \multicolumn{2}{|c|}{$\mathrm{A}=0.12$} & \multicolumn{2}{|c|}{$\mathrm{N} \times \mathrm{A}=0.23$} \\
\hline
\end{tabular}

Similar results were found by Ahmed and El-Azim (2009) on Ochradenus baccatus and Ibrahim et al. (2011) on Labisia pumila.

Furthermore, the increase in the above mentioned parameters due to the used nitrogen fertilization treatments might be directly or indirectly due to the activation of the anabolic processes of carbohydrates metabolism. This nutrient might participate in chlorophyll anabolism, leading to more volatile oil content.

\section{Effect of amino acids type:}

It is quite clear from data presented in Table (5) that, in most cases, volatile oil percentage and volatile oil yield per plant and per feddan of coriander plant were significantly increased by using amino acid types as compared to control (untreated plants) in the first and second seasons. Meantime, the highest values in this regard were obtained from the treatment of combination between the two types of amino acid (L- tryptophan + phenylalanine) at 150 ppm of each one compared to the other treatments under study during both seasons. Similar results were found by EL-Zefzafy et al. (2016) who reported that Artemisia essential oil parameters were gradually increased with increasing amino acids or citric acid concentrations. 


\section{Effect of interaction between nitrogen fertilization and amino acids:}

Results in Table (5) suggest that, volatile oil production of coriander fruits was increased with all interaction treatments between nitrogen fertilization rates and amino acids type compared with control [control $\mathrm{N}$ (0 rate) and without foliar spray by amino acids] in both seasons. Moreover, the interaction treatment between the recommended rate of nitrogen and Ltryptophan plus phenylalanine was superior in this respect followed by the combined treatment of $75 \%$ and L-tryptophan plus phenylalanine compared to the other treatments under study in the first and second seasons.

Also, under each nitrogen fertilization rate treatment volatile oil percentage and volatile oil yield per plant and per feddan were increased by using amino acid types, in most cases. Likewise, under each treatment of amino acid types volatile oil production of coriander was mostly increased with increasing nitrogen fertilization rates.

Furthermore, the recommended rate of nitrogen and L-tryptophan plus phenylalanine treatment raised volatile oil yield/plant over the combined treatment of $75 \%$ and L-tryptophan plus phenylalanine by 18.0 and $6.8 \%$ in the two seasons, respectively, while the combined treatment of $75 \%$ from recommended rate of nitrogen and L-tryptophan plus phenylalanine raised volatile oil yield/plant over the control by 125.9 and $102.8 \%$ and over $100 \%+$ control treatment by 48.8 and $55.3 \%$ during the $1^{\text {st }}$ and $2^{\text {nd }}$ seasons, respectively.

These results coincided with those reported by Janmohammadi et al. (2014) on Dracocephalum moldavica who found that chemical fertilization increased oil yield compared to unfertilized plants. Also, Talaat and Youssef (2002) and Omer et al. (2013) mentioned that, foliar application of amino acids significantly increased essential oil percentage and yield.

\section{Chemical constituents:}

\section{Effect of nitrogen fertilization rates:}

As shown in Tables (6 and 7) that, the treatment of recommended rate of nitrogen fertilization increased total nitrogen, phosphorus and potassium as well as total carbohydrates percentages of coriander fruits compared with the other ones under study. However, the coriander chemical constituents were increased with increasing nitrogen rates, in most cases. Generally, all nitrogen fertilization rate treatments increased the abovementioned parameters compared with control. Such results hold true in both seasons.

These results are in harmony with those reported by Albayrak and Yuksel (2010) on fodder beet and Abdelkader et al. (2012) on roselle and guar plants. The accumulation of carbohydrates as a result of nitrogen application may be due to the important role of nitrogen in the biosynthesis of chlorophyll molecules (Meyer et al., 1968).

\section{Effect of amino acids type:}

It is evident from the obtained results in Tables (6 and 7) that, the maximum increase in total nitrogen, phosphorus and potassium as well as total carbohydrates percentages of coriander plant were obtained from the treatment of L-tryptophan plus phenylalanine compared with the other treatments under study. Such increase was significant in the two consecutive seasons, in most cases. Meantime, chemical constituents of coriander fruits were significantly increased with all amino acid types compared with control during both seasons. These results are in line with those reported by Attoa et al. (2002) on Iberis amara plant and Gomaa (2003) on Crinum asiaticum plant.

\section{Effect of the interaction between nitrogen fertilization and amino acids:}

Results in Tables (6 and 7) indicate that, total nitrogen, phosphorus and potassium as well as total carbohydrates percentages in coriander fruits were significantly increased with all interaction treatments between 
Table 6. Effect of nitrogen fertilization rates $(\mathrm{N})$, amino acids type (A) and their interaction $(\mathrm{N} \times \mathrm{A})$ treatments on nitrogen and phosphorus percentages of coriander plant during $2016 / 2017$ and $2017 / 2018$ seasons.

\begin{tabular}{|c|c|c|c|c|c|c|c|c|c|c|}
\hline \multirow[b]{2}{*}{$\begin{array}{c}\text { Nitrogen } \\
\text { fertilization } \\
\text { rates (kg N/fed) }\end{array}$} & \multicolumn{10}{|c|}{ Amino acids type } \\
\hline & 0.0 & Tryp. & $\begin{array}{c}\text { Phen. } \\
\text { 2016/2017 }\end{array}$ & $\begin{array}{l}\text { Tryp. } \\
\text { +Phen. } \\
7\end{array}$ & $\begin{array}{c}\text { Mean } \\
\text { (N) }\end{array}$ & 0.0 & Tryp. & $\begin{array}{l}\text { Phen. } \\
\text { 2017/2018 }\end{array}$ & $\begin{array}{l}\text { Tryp. } \\
\text { +Phen. } \\
\end{array}$ & $\begin{array}{c}\text { Mean } \\
\text { (N) }\end{array}$ \\
\hline & \multicolumn{10}{|c|}{ Total nitrogen $\%$ in fruits } \\
\hline Control & 2.083 & 2.150 & 2.197 & 2.253 & 2.171 & 2.157 & 2.187 & 2.270 & 2.403 & 2.254 \\
\hline $50 \% \mathrm{RR}^{*}$ & 2.110 & 2.260 & 2.277 & 2.393 & 2.260 & 2.180 & 2.267 & 2.343 & 2.413 & 2.301 \\
\hline $75 \%$ RR & 2.103 & 2.313 & 2.377 & 2.350 & 2.286 & 2.180 & 2.297 & 2.367 & 2.460 & 2.326 \\
\hline $100 \%$ RR & 2.230 & 2.317 & 2.467 & 2.677 & 2.422 & 2.253 & 2.333 & 2.513 & 2.753 & 2.463 \\
\hline Mean (A) & 2.132 & 2.260 & 2.329 & 2.418 & & 2.192 & 2.271 & 2.373 & 2.508 & \\
\hline \multirow[t]{2}{*}{ LSD at $5 \%$} & \multirow{2}{*}{\multicolumn{2}{|c|}{$\mathrm{N}=0.071$}} & \multirow[t]{2}{*}{$A=0.038$} & \multicolumn{2}{|c|}{$\mathrm{N} \times \mathrm{A}=0.075$} & $\mathrm{~N}=0.034$ & \multicolumn{2}{|c|}{$A=0.046$} & \multicolumn{2}{|c|}{$\mathrm{N} \times \mathrm{A}=0.087$} \\
\hline & & & & \multicolumn{4}{|c|}{ Total phosphorus \% in fruits } & & & \\
\hline Control & 0.267 & 0.313 & 0.333 & 0.363 & 0.319 & 0.303 & 0.313 & 0.340 & 0.363 & 0.330 \\
\hline $50 \%$ RR* & 0.310 & 0.350 & 0.357 & 0.377 & 0.348 & 0.323 & 0.327 & 0.357 & 0.373 & 0.345 \\
\hline $75 \%$ RR & 0.353 & 0.377 & 0.387 & 0.417 & 0.383 & 0.347 & 0.377 & 0.387 & 0.410 & 0.380 \\
\hline $100 \%$ RR & 0.360 & 0.370 & 0.397 & 0.427 & 0.388 & 0.377 & 0.387 & 0.397 & 0.440 & 0.400 \\
\hline Mean (A) & 0.322 & 0.353 & 0.368 & 0.396 & & 0.337 & 0.351 & 0.370 & 0.397 & \\
\hline LSD at $5 \%$ & \multicolumn{2}{|l|}{$\mathrm{N}=0.008$} & $A=0.008$ & \multicolumn{2}{|c|}{$\mathrm{N} \times \mathrm{A}=0.015$} & $\mathrm{~N}=0.007$ & \multicolumn{2}{|c|}{$A=0.011$} & \multicolumn{2}{|c|}{$\mathrm{N} \times \mathrm{A}=0.022$} \\
\hline
\end{tabular}

Table 7. Effect of nitrogen fertilization rates $(\mathrm{N})$, amino acids type (A) and their interaction $(\mathrm{N} \times \mathrm{A})$ treatments on potassium and carbohydrates percentages of coriander plant during $2016 / 2017$ and $2017 / 2018$ seasons.

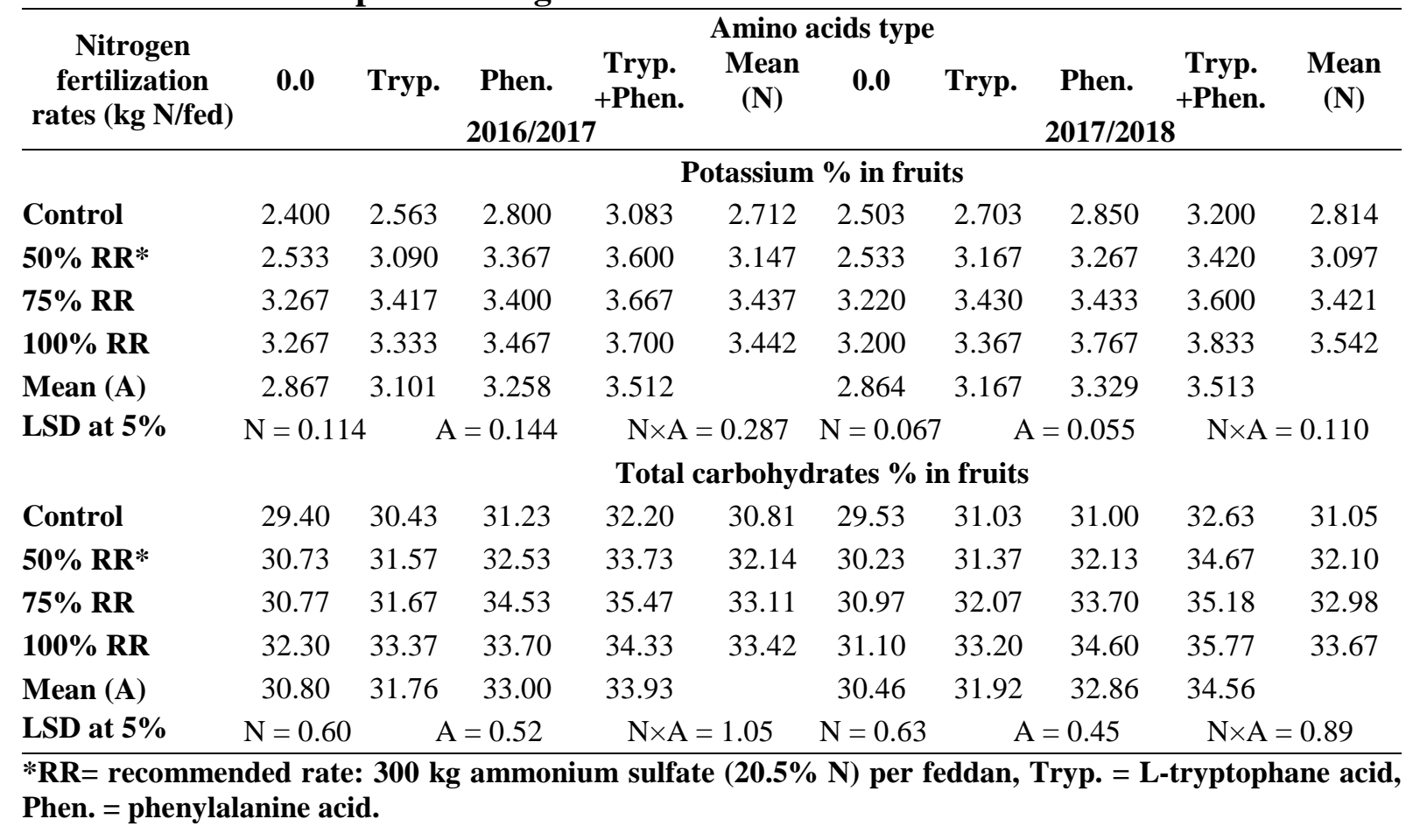


nitrogen fertilization rates and amino acid types compared with control, in most cases, in both seasons. However, under either nitrogen fertilization rate treatments chemical constituents of coriander fruits were increased by using amino acids type treatments, in most cases.

In addition, the best interaction treatment in this regard was $\mathrm{N}$ (recommended rate) and L- tryptophan plus phenylalanine compared to the other treatments under study such increase was significant, in most cases, in the two seasons.

The stimulatory effect of the treatments of nitrogen fertilization plus amino acids on coriander chemical constituents might be due to the role of nitrogen on the plant physiological processes and amino acids which was previously mentioned in the case of $\mathrm{N}, \mathrm{P}$ and $\mathrm{K}$ percentages of coriander fruits as the increase in these parameters was reflected on higher concentration of chemical constituents of coriander fruits.

Insect, mite pests and associated natural enemies:
Survey of insect and mite pests infested coriander plants:

The results in Tables (8) reveal that, the coriander plants found infested by more species [three aphids as: coriander aphids, (Hyadaphis coriandri (Das); cotton aphids, Aphis gossypii (Glov.); green peach aphids, Myzus persicae (Sulz)]; cotton whitefly, Bemisia tabaci (Genn.); onion thrips, Thrips tabaci (Lind.); Two spotted spider mite, Tetranychus urticea (Koch).

The $H$. coriandri insects and T. urticea were the dominant piercing-sucking pests infesting coriander plants and represented highest mean numbers of $39.00\left(2^{\text {nd }}\right.$ season $)$ and $35.00\left(1^{\text {st }}\right.$ season) individuals/plant for the two pests; followed by the onion thrips, T. tabaci with mean numbers of $19.00\left(2^{\text {nd }}\right.$ season) individuals/plant in plots received 100\% nitrogen and sprayed by Tryp. + Phen. The obtained results were found in agreement with those of Salem et al. (2016) who reported that the aphids (different species) were the most abundant piercingsucking insect pests on coriander plants.

Table 8. Survey of pests infested coriander plants and associated natural enemies at ELQuassasin district, Ismailia, Governorate, Egypt during 2016/2017 and 2017/2018 seasons.

\begin{tabular}{|c|c|c|c|c|c|}
\hline English name & Scientific name & Arabic name & Family name & Order name & $\begin{array}{c}\text { Occurrence } \\
\text { level }\end{array}$ \\
\hline & \multicolumn{5}{|c|}{ Pest infested coriander plants } \\
\hline Aphids & $\begin{array}{l}\text { Hyadaphis coriandri } \\
\text { (Das), } \\
\text { Aphis gossypii (Glov.) } \\
\text { Myzus persicae (sulz) }\end{array}$ & $\mathrm{Al}$ men & Aphididae & Homoptera & $\begin{array}{l}++++ \\
\quad+ \\
+\end{array}$ \\
\hline Cotton whitefly & Bemisia tabaci (Genn.) & Zobaba bidaa & Alerodidae & Homoptera & ++ \\
\hline Onion thrips & Thrips tabaci (Lind.) & Treps & Thrpidae & Thaythanoptera & ++ \\
\hline Two spotted spider mite & $\begin{array}{l}\text { Tetranychus urticea } \\
\text { (Koch) }\end{array}$ & Acaros & Tetranychidae & Acari & ++++ \\
\hline \multicolumn{6}{|c|}{ Associated natural enemies } \\
\hline Syrphus & $\begin{array}{l}\text { Syrphus spp. } \\
\text { Aphidus spp. }\end{array}$ & Zobab el serfus & ssyrphidae & Diptera & + \\
\hline Aphids mummies & $\begin{array}{l}\text { Lysiphlebus sp. } \\
\text { Diaeretiella sp }\end{array}$ & Tofiliat al men & Aphidiidae & Hymenoptera & ++ \\
\hline Ladybirds beetles & Coccinella spp. & Abo el eid & Coccinellidae & Coleoptera & ++ \\
\hline Green lacewing & $\begin{array}{l}\text { Chrisoprella } \\
\text { (Steph) }\end{array}$ & Asad al men & Chrysopidae & Neuroptera & ++ \\
\hline Predacious mite & $\begin{array}{l}\text { Phytoseiulus sp. } \\
\text { Euseius sp. }\end{array}$ & $\begin{array}{l}\text { Moftersate } \\
\text { acaros }\end{array}$ & Phytoseiidae & Acari & ++ \\
\hline
\end{tabular}




\section{Survey of associated natural enemies:}

The results in Tables (8 and 10) show that, the visual count of aphid mummies colored dark to light brown or a brassy brown with spherical round shape were recorded on coriander plants in relatively low mean number of 6.00 mummy/plant during the second study season. The noticed mummies color gave clear indication about parasitoids species (Aphidius spp., Diaeretiella rapae, and Lysiphlebus testaceipes Cresson (Hymenoptera: Aphidiidae) which parasitized the surveyed aphids species, as found by the results of ElHeneidy and Adly (2009).

In the same trend, the results recorded three insect predators (Coccinella spp., Chrisoprella carnea (Steph) and Syrphus sp.) but the Coccinella spp. and C. carnea were the dominant predators and presented relatively low mean numbers of 7.00 and 3.67 individuals/plant during the second season, respectively.

Also, the phytoseiid predator mites, Phytoseiulus sp. and Euseius sp. were found as dominant phytoseiid predator species but in relatively low numbers associated with pests on coriander during the two seasons, respectively. The obtained results were found in agreement with those of Gallardo et al. (2005) who mentioned that the Euseius predator mites was found as dominant phytoseiid predator mite's species associated with phytophagous mite.

\section{Effect of nitrogen fertilization, amino acids and their interaction on the mean numbers of coriander pests:}

The results presented in Table (9) revealed that, there were significant differences $(\leq 0.05)$ between the mean numbers of piercing and sucking pests which varied depending on the variation of nitrogen rates and amino acid types, where the highest mean numbers of the dominant piercingsucking pests infesting coriander plants, $H$. coriandri, T. tabaci insects and T. urticea represented the highest mean numbers of (38.33 \& 39.00), (16.67 \& 19.00) and (35.00
\& 23.33) individuals/plant for the three pests, during the two study seasons of 2016/2017 and 2017/2018, respectively, in plots which received $100 \%$ nitrogen (recommended rate) and sprayed by Ltryptophan and phenylalanine.

The cotton whitefly was occurred in low mean numbers in all treatments with relatively high mean numbers of 7.00 and 8.00 individuals/plant during the two study seasons of 2016/2017 and 2017/2018, respectively, in plots which received $100 \%$ nitrogen (recommended rate) and sprayed by L-tryptophan and phenylalanine.

The effect of biotic (pests) and abiotic (soil and climate) factors on coriander yield can be deduced as the differences between the expected mean fruits yield ranged from 1.21 to 1.56 ton/feddan recorded in $\mathrm{Al}$ Gharbia and $\mathrm{Al}$ Fayoum Governorates, respectively [recorded throughout the period extended from 1998 to 2012 period (AbdelHafiz and Elsoguar, 2013) and that recorded in this trial which reached 0.958 ton/feddan. The differences between the expected mean fruits yield and that recorded in this experiment $=((1.21+1.56) / 2)-0.958=0.427$ ton/feddan

The obtained results agreed with those of Dawood (1971); Hussien (1982); EL-Gendi (1988); El-Kordy et al. (1999); Ismail (2001), Pons and Lumbierres (2004) and Meena et al (2011) which summarized that aphids are considered to be the most serious pests and caused serious reduction in the annual yield of coriander, ornamental and aromatic plants.

Effect of nitrogen fertilization, amino acids and their interaction on the mean numbers of associated natural enemies:

The results given in Table (10) clear that, there were significant differences $(\leq$ 0.05 ) between the mean numbers of natural enemies (predators and aphids mummies) associated with pests on coriander plant during 2016/2017 and 2017/2018 seasons, which varied depending on the variation of pests number and coriander plant 
Table 9. Effect of nitrogen fertilization rates $(\mathrm{N})$, amino acids type (A) and their interaction $(\mathrm{N} \times \mathrm{A})$ treatments on the mean number of pests of coriander plant during 2016/2017 and 2017/2018 seasons.

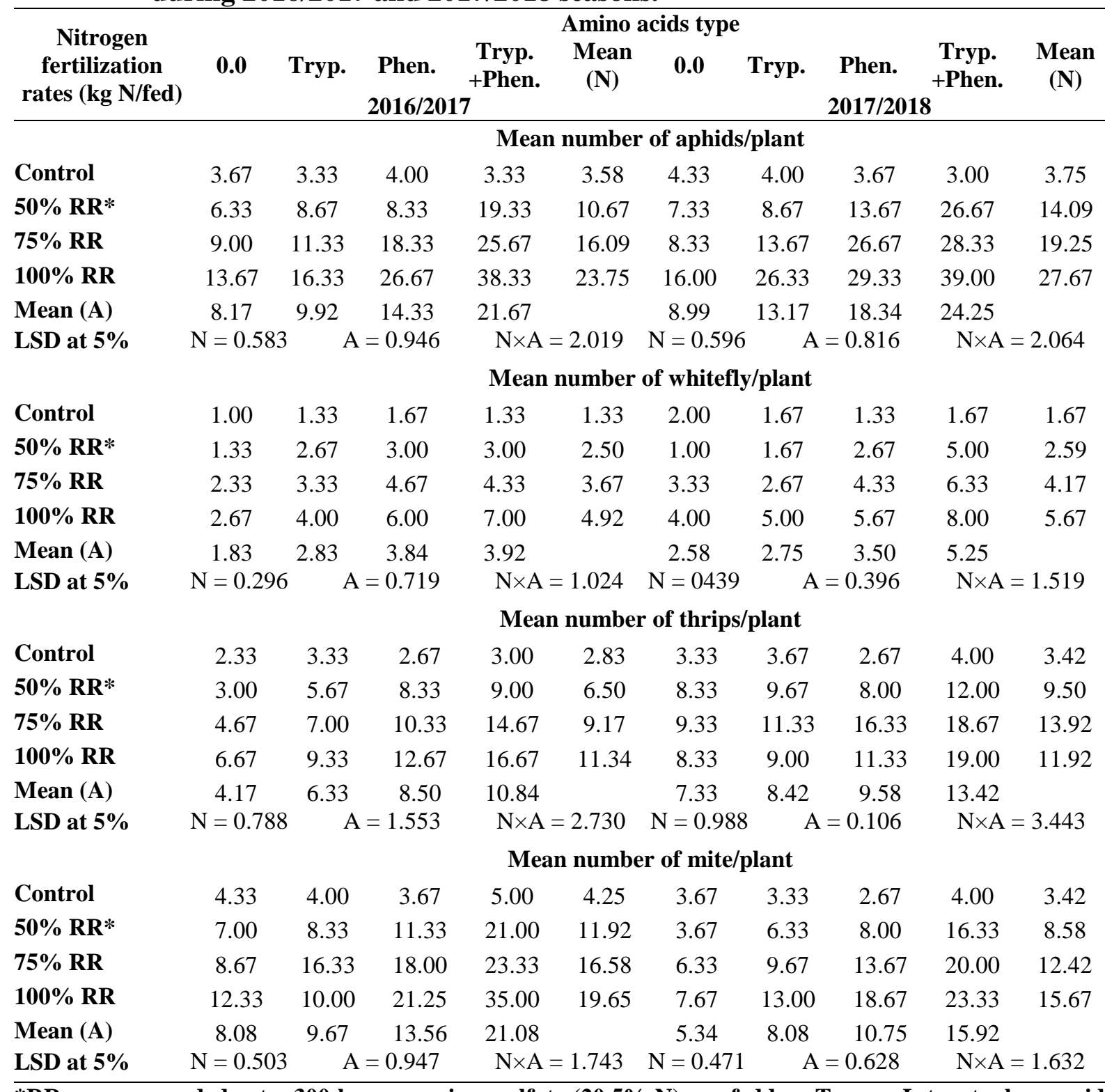

* $\mathrm{RR}=$ recommended rate: $300 \mathrm{~kg}$ ammonium sulfate $(20.5 \% \mathrm{~N})$ per feddan, Tryp. = L-tryptophane acid, Phen. $=$ phenylalanine acid.

characteristics followed the variances in nitrogen rates and amino acid types, where the highest mean numbers of the dominant predator, ladybirds beetles and predacious mite represented the highest mean numbers of (6.67 \& 7.00) and (6.00 \& 7.33) individuals/plant for the two predators, during the two seasons of 2016/2017 and 2017/2018, respectively, in plots received
100\% nitrogen (recommended rate) and sprayed by L-tryptophan and phenylalanine, that infested by the highest numbers of pests. The obtained results agreed with those of Swami et al. (2018) who mentioned that, the coccinellids beetles were the dominant predators associated with insect pests infested coriander plants. 
Table 10. Effect of nitrogen fertilization rates $(N)$, amino acids type $(A)$ and their interaction $(\mathrm{N} \times \mathrm{A})$ treatments on the mean number of natural enemies associated with pests of coriander plant during 2016/2017 and 2017/2018 seasons.

\begin{tabular}{|c|c|c|c|c|c|c|c|c|c|c|}
\hline \multirow[b]{2}{*}{$\begin{array}{c}\text { Nitrogen } \\
\text { fertilization } \\
\text { rates }(\mathrm{kg} N / \mathrm{fed})\end{array}$} & \multicolumn{10}{|c|}{ Amino acids type } \\
\hline & 0.0 & Tryp. & $\begin{array}{l}\text { Phen. } \\
\text { 2016/2017 }\end{array}$ & $\begin{array}{l}\text { Tryp. } \\
\text { +Phen. } \\
7\end{array}$ & $\begin{array}{c}\text { Mean } \\
(\mathbf{N})\end{array}$ & \multicolumn{5}{|c|}{ 2017/2018 } \\
\hline & \multicolumn{10}{|c|}{ Mean number of ladybird beetles/plant } \\
\hline Control & 0.67 & 0.33 & 1.00 & 0.67 & 0.67 & 1.33 & 0.67 & 0.67 & 1.00 & 0.917 \\
\hline $50 \% \mathbf{R R}^{*}$ & 0.33 & 1.33 & 2.33 & 3.67 & 1.92 & 0.67 & 2.00 & 4.33 & 4.67 & 2.92 \\
\hline $75 \%$ RR & 1.00 & 1.33 & 3.67 & 5.33 & 2.83 & 0.67 & 3.33 & 5.00 & 6.00 & 3.75 \\
\hline $100 \%$ RR & 1.67 & 1.67 & 3.00 & 6.67 & 3.25 & 1.33 & 4.00 & 4.67 & 7.00 & 4.25 \\
\hline Mean (A) & 0.92 & 1.17 & 2.50 & 4.09 & 2.17 & 1.00 & 2.50 & 3.67 & 4.67 & 2.96 \\
\hline \multirow[t]{2}{*}{ LSD at $5 \%$} & \multicolumn{2}{|c|}{$\mathrm{N}=0.500$} & $A=0.599$ & \multicolumn{2}{|c|}{$\mathrm{N} \times \mathrm{A}=1.733$} & \multicolumn{2}{|c|}{$\mathrm{N}=0.805$} & $A=0.478$ & \multicolumn{2}{|c|}{$\mathrm{N} \times \mathrm{A}=2.787$} \\
\hline & \multicolumn{10}{|c|}{ Mean number of green lacewing/plant } \\
\hline Control & 0.33 & 1.00 & 0.67 & 0.33 & 0.58 & 0.67 & 0.67 & 1.00 & 1.33 & 0.92 \\
\hline $50 \% \mathrm{RR}^{*}$ & 0.33 & 0.67 & 1.00 & 1.67 & 0.92 & 0.33 & 0.67 & 1.33 & 2.33 & 1.17 \\
\hline $75 \% \mathbf{R R}$ & 0.67 & 1.00 & 1.67 & 2.33 & 1.42 & 0.33 & 0.67 & 1.67 & 2.67 & 1.34 \\
\hline $100 \%$ RR & 0.67 & 1.33 & 2.00 & 2.67 & 1.67 & 1.00 & 1.33 & 2.33 & 3.67 & 2.08 \\
\hline Mean (A) & 0.50 & 1.00 & 1.34 & 1.75 & 1.15 & 0.58 & 0.84 & 1.58 & 2.50 & 1.38 \\
\hline \multirow[t]{2}{*}{ LSD at $5 \%$} & \multicolumn{2}{|c|}{$\mathrm{N}=0.429$} & $A=0.535$ & \multicolumn{2}{|c|}{$\mathrm{N} \times \mathrm{A}=1.486$} & \multicolumn{2}{|c|}{$\mathrm{N}=0.353$} & $A=0.629$ & \multicolumn{2}{|c|}{$\mathrm{N} \times \mathrm{A}=1.224$} \\
\hline & \multicolumn{10}{|c|}{ Mean number of mite predators/plant } \\
\hline Control & 1.00 & 1.33 & 2.00 & 1.67 & 1.50 & 1.33 & 2.00 & 1.67 & 1.67 & 1.67 \\
\hline $50 \% \mathbf{R R}^{*}$ & 2.00 & 2.33 & 3.33 & 4.67 & 3.08 & 1.67 & 2.33 & 3.67 & 5.00 & 3.17 \\
\hline $75 \%$ RR & 2.33 & 3.67 & 4.67 & 5.33 & 4.00 & 2.00 & 2.67 & 4.33 & 6.00 & 3.75 \\
\hline $100 \%$ RR & 3.00 & 3.67 & 5.00 & 6.00 & 4.42 & 2.33 & 3.67 & 5.33 & 7.33 & 4.67 \\
\hline Mean (A) & 2.08 & 2.75 & 3.75 & 4.42 & 3.25 & 1.83 & 2.67 & 3.75 & 5.00 & 3.31 \\
\hline \multirow[t]{2}{*}{ LSD at $5 \%$} & \multicolumn{2}{|c|}{$\mathrm{N}=0.455$} & $A=0.865$ & \multicolumn{2}{|c|}{$\mathrm{N} \times \mathrm{A}=1.576$} & \multicolumn{2}{|c|}{$\mathrm{N}=2.568$} & $A=3.237$ & \multicolumn{2}{|c|}{$\mathrm{N} \times \mathrm{A}=0.889$} \\
\hline & \multicolumn{10}{|c|}{ Mean number of aphids mummies/plant } \\
\hline Control & 1.00 & 2.33 & 2.00 & 2.00 & 1.83 & 2.33 & 1.67 & 2.33 & 2.00 & 2.08 \\
\hline $50 \% \mathrm{RR}^{*}$ & 1.33 & 2.67 & 3.00 & 3.67 & 2.67 & 1.33 & 1.67 & 2.67 & 4.33 & 2.50 \\
\hline $75 \%$ RR & 2.33 & 2.67 & 4.33 & 4.33 & 3.42 & 1.67 & 2.33 & 2.67 & 4.67 & 2.84 \\
\hline $100 \%$ RR & 2.67 & 3.33 & 4.67 & 5.00 & 3.92 & 2.00 & 4.00 & 5.33 & 6.00 & 4.33 \\
\hline Mean (A) & 1.83 & 2.75 & 3.50 & 3.75 & 2.96 & 1.83 & 2.42 & 3.25 & 4.25 & 2.94 \\
\hline LSD at $5 \%$ & \multicolumn{2}{|c|}{$\mathrm{N}=0.570$} & $A=0.288$ & \multicolumn{2}{|c|}{$\mathrm{N} \times \mathrm{A}=1.976$} & \multicolumn{2}{|c|}{$\mathrm{N}=0.226$} & $A=0.394$ & \multicolumn{2}{|c|}{$\mathrm{N} \times \mathrm{A}=0.782$} \\
\hline
\end{tabular}

* $\mathrm{RR}=$ recommended rate: $300 \mathrm{~kg}$ ammonium sulfate $(20.5 \% \mathrm{~N})$ per feddan, Tryp. = L-tryptophane acid, Phen. $=$ phenylalanine acid.

In the same trend the highest mummies numbers of 5.00 and 6.00 mummy/plant were associated with the highest aphids colonies in number infested coriander plants with the highest plant height and branch numbers in plots which received 100\% nitrogen (recommended rate) and sprayed by L-tryptophan and phenylalanine, during the two seasons of 2016/2017 and 2017/2018, respectively. The obtained results found in agreement with those mentioned by Mendes et al. (2015) who reported that, each of parasitoids Aphidius spp., Diaeretiella rapae, and Lysiphlebus testaceipes Cresson (Hymenoptera: Aphidiidae) were associated with aphids species on coriander plants and caused aphids mummification.

\section{Correlation study:}

The calculated correlation coefficient illustrated in Table (11) reveal positive, strong and highly significant relationships 
Table 11. The correlation relationship between vegetative growth (plant height and number of branches) with insect and mite pests (Aphids, Two spotted spider mite and Onion thrips) under nitrogen fertilizer rates, amino acids types and the combined treatments between them during 2016/2017 and 2017/2018 seasons.

\begin{tabular}{lcccc}
\hline \multirow{2}{*}{ The investigates pests } & \multicolumn{2}{c}{ Plant height } & \multicolumn{2}{c}{ Number of branches } \\
& $\mathbf{1}^{\text {st }}$ season & $\mathbf{2}^{\text {nd }}$ season & $\mathbf{1}^{\text {st }}$ season & $\mathbf{2}^{\text {nd }}$ season \\
\hline & & \multicolumn{4}{c}{ Nitrogen fertilizer (N) } \\
Aphids & $0.784^{\mathrm{NS}}$ & $0.633^{\mathrm{NS}}$ & $0.988^{* *}$ & $0.990^{* *}$ \\
Two spotted spider mite & $0.826^{\mathrm{NS}}$ & $0.709^{\mathrm{NS}}$ & $0.998^{* *}$ & $0.988^{* *}$ \\
Onion thrips & $0.827^{\mathrm{NS}}$ & $0.859^{\mathrm{NS}}$ & $0.999^{* *}$ & $0.901^{\mathrm{NS}}$ \\
& & Amino acids (A) \\
Aphids & $0.960^{*}$ & $0.999^{* *}$ & $0.957^{*}$ & $0.938^{*}$ \\
Two spotted spider mite & $0.969^{*}$ & $0.989^{* *}$ & $0.959^{*}$ & $0.965^{*}$ \\
Onion thrips & $0.862^{\mathrm{NS}}$ & $0.957^{*}$ & $0.955^{*}$ & $0.966^{*}$ \\
& & & \\
Aphids & $0.769^{* *}$ & $0.667^{* *}$ & $0.877^{* *}$ & $0.861^{* *}$ \\
Two spotted spider mite & $0.787^{* *}$ & $0.737^{* *}$ & $0.846^{* *}$ & $0.903^{* *}$ \\
Onion thrips & $0.761^{* *}$ & $0.696^{* *}$ & $0.884^{* *}$ & $0.801^{* *}$ \\
\hline
\end{tabular}

between mean numbers of investigated pests and coriander plant characteristics, especially for aphids, mite and thrips with branches numbers as nitrogen rates effect during the two study seasons, respectively.

The same trend was recorded for the relationships between mean numbers of investigated pests and coriander plant characteristics with positive and significant correlations under amino acid types effect. Furthermore, the relationships between mean numbers of investigated pests and coriander plant characteristics under the combined treatments were highly significant and positive in plant height and stronger with number of branches during both seasons.

The significant correlation between mean numbers of investigated pests and coriander plant characteristics, especially with branches number and plant height return to the favorable micro-ecosystem condition (suitable temperature and relative humidity) which provided to inspected pests by the high numbers and interlock of branches resulted as response to high nitrogen rates and amino acid types.

\section{Conclusion:}

The results of this study show that there is a convergence of results between the interaction treatments of $(300 \mathrm{~kg}$ of ammonium sulfate plus L-tryptophan + phenylalanine acids at $150 \mathrm{ppm})$ and (225 kg of ammonium sulfate plus L- tryptophan + phenylalanine acids at $150 \mathrm{ppm}$ ) with all the studied characters in this study. Furthermore, there were non-significant difference between them in many characters as plant height, number of branches, fresh and dry weights of herb/plant, fresh and dry weights of roots/plant, number of umbels/plant, number of florets/umbels/plant, fruit yield/plant and fruit yield/fed. as well as percentages of volatile oil, nitrogen, phosphorus, potassium and carbohydrates. So we can recommend to use the nitrogen at $225 \mathrm{~kg}$ of ammonium sulfate/fed plus Ltryptophan + phenylalanine acids at $150 \mathrm{ppm}$ three times a season to enhance the vegetative growth, yield components and chemical constituents in fruits as well as volatile oil productivity of coriander (Coriandrum sativum L.) plants under Ismailia Governorate conditions. 
In the same trend, highly significant differences $(\leq 0.05)$ between the mean numbers of the piercing-sucking pest's infestation; i.e., Hyadaphis coriandri (Das), Bemisia tabaci (Genn.), Thrips tabaci (Lind.), Tetranychus urticea Koch., and its associated natural enemies; i.e., Coccinella spp., Chrisoprella carnea (Steph.), aphids parasitoids and predators mite species were resulted due to the variation in nitrogen fertilization rates, and foliar spray of amino acids types. Also, the simple correlation calculation revealed significant coefficients for the relation between each of surveyed pests and associated natural enemies correlated with growth parameters (plant height, number of branches/plant) and seed yield/plant.

\section{REFERENCES}

Abd El-Hafiz, R.A. and Elsoguar, G.A. (2013). Efficiency of production and export coriander crop in Egypt. Assiut J. Agric. Sci., 44(1):79-92.

Abd EL-Kareim, A.I.; EL-Negar, M.E. and Marouf, A.E. (2011). Survey of predaceous insects associated with four medicinal plants. J. Plant Prot. and Pathology, Mansoura University, 2(6):623-636.

Abd EL-Moniem, A.S.H. and Abd ELWahab, T.E. (2006). Insect pests and predators inhabiting roselle plants, Hibiscus sabdariffa L., a medicinal plant in Egypt. Archives of Phytopathology and Plant Protec., 39(1):25-32.

Abdelkader, M.A.; El-Shamy, H.A.; Meawad, A.A. and Bishr, G.A. (2012). Yield components and active ingredients of roselle and guar as influenced by intercropping system and nitrogen fertilization rate. Zagazig J. Agric. Res., 39(2):157-166.

Abdel-Motagally, F.M.F. and Attia, K.K. (2009). Response of sugar beet plants to nitrogen and potassium fertilization in sandy calcareous soil. Int. J. Agric. Biol., 11(6):695-700.
Abou Dahab, T.A.M. and Abd El-Aziz, N.G. (2006). Physiological effect of diphenylamine and tryptophan on the growth and chemical constituents of Philodendron erubescens. World J. of Agric. Sci., 2(1):75-81.

Afsha, A.F.E. (2005). Studies on Some Pests Attacking Medicinal and Aromatic Plants. Ph.D. Thesis, Fac. Agric., Zagazig Univ., 205 p.

Ahmed, S.T. and El-Azim, W.M.A. (2009). Effect of irrigation intervals and nitrogen fertilization on growth and active ingredients of (Ochradenus baccatus Del.) plants under Mariut conditions. Egyptian Journal of Horticulture, 36(2):301-314.

Albayrak, S. and Yuksel, O. (2010). Effect of nitrogen fertilization and harvest time on root yield and quality of fodder beet (Beta vulgaris var. crassa Mansf.). Turkish Journal of Field Crops, 15(1):5964.

Ali, A.G. (1988). Ecological and Control Studies on Certain Pests Infesting Medicinal and Aromatic Plants. Ph.D. Thesis, Fac. Agric., Assiut Univ., 297 p.

Allahdadi M. and Farzane, P. (2018). Influence of different levels of nitrogen fertilizer on some phytochemical characteristics of artichoke (Cynara scolymus L.) leaves. Journal of Medicinal Plants Studies, 6(1):109-115.

Al-Qarni, A.S. (2005). Destructive and beneficial insects associated with two medicinal plants (Coriandrum sativum and Brossica nigra) in Central Saudi Arabia. Minia J. Agric. Res. \& Dev., 25(2):329-344.

Analytical Software (2008). Statistix Version 9, Analytical Software, Tallahassee, Florida, USA.

A.O.A.C. (1990). Official Methods of Analysis. $15^{\text {th }}$ Ed. Association of Official Analytical Chemists, Inc., Virginia, USA. 
Attoa, G.E.; Wahba, H.E. and Farahat, A.A. (2002). Effect of some amino acids and sulphur fertilization on growth and chemical composition of Iberis amara L. plants. Egypt. J. Hort., 29:17-37.

Butani, D.K. (1984). Species and pest problems: 3-Coriander, pesticides, 18:1517.

Chapman, D.H. and Pratt, R.F. (1978). Methods Analysis for Soil, Plant and Water. Univ. of California Div. Agric. Sci.

Chaudhary, H.C.; Singh, D. and Singh, R. (2009). Diversity of aphids (Homoptera: Aphididae) on the field crops in Terai of Eastern Uttar Pradesh. J. Aphidology, 23(1\&2):69-76.

Davies, D.D. (1982). Physiological aspects of protein turn over. Encycl. Plant Physiology. New Series, 14 A (Nucleic Acids and Proteins: Structure Biochemistry and Physiology of Proteins). 190-288 - Ed., Boulter, D. and Par.

Dawood, M.Z. (1971). Survey of Aphids and Mealy-bugs Infesting Ornamental Plants. M.Sc. Thesis., Fac. Agric., Cairo Univ., Egypt, 114 p.

Devlin, R.M. (1979). Plant Physiology. Third Edition. Affiliated East. West. Press Prt. Ltd. New Delhi, Madras India.

Dubois, M.; Gilles, K.A.; Robers, J.H. and Smith, F. (1956). Colorimetric methods for determination of sugar and related substances. Anal. Chem., 28:350-356.

EL-Gendi, S.S.M.M. (1988). Ecological and Biological Studies on Some Insect Pests of Ornamental and Medicinal Plants. Ph.D. Thesis, Fac. Agric., EL-Fayoum, Cairo Univ., 170 pp.

El-Heneidy, A.H. and Adly, D. (2009). Discrimination among aphid parasitoids through characteristics of their mummies. Egyptian, J. Bio. Pest Cont., 19(1):37-40.

EL-Kordy, M.W.; Mohamed, A.A.; Marzouk, I.A. and Mohamed, H.A.
(1999). The changes in population density of aphids attacking some medicinal and aromatic plants in Egypt. Egypt J. Agric. Res., 77(1):195-204.

EL-Sayed, A.M.; Abd EL-Galil, F.A.; Darwish, Y.A. and Abou Elhagag, G.H. (1990). Incidence and dominance of arthropods associated with roselle, caraway and coriander plants in Upper Egypt. Assuit J. Agric. Sci., 21(3):153165.

EL-Sayed, H.A.M. (1993). Studies on Aphid Fauna Infesting Medicinal and Aromatic Plants in Egypt. M.Sc. Thesis, Fac. of Agric., AL-Azhar Univ.

EL-Zefzafy, M.M.; Shahhat, I.M. A.; Yousef, R.S. and Elsharkawy, E.R. (2016). Influence of foliar application with amino acids and citric acid on physiological and phytochemical responses of Artemisia abrotanum produced by in vitro culture. Biosci. Biotech. Res. Comm., 9(4):702-711.

Emamghoreishi, M.; Khasaki, M. and Aazam, M.F. (2005). Coriandrum sativum: evaluation of its anxiolytic effect in the elevated plus-maze. J. Ethnopharmaco, 96:365-370.

Ezz El-Din, A.A.; Hendawy, S.F.; Aziz, E.E. and Omer, E.A. (2010). Enhancing growth, yield and essential oil of caraway plants by nitrogen and potassium fertilizers. Int. J. of Acad. Res., 2(3):192197.

Gallardo A.; Vasquez, C.; Morales, J. and Gallardo, J. (2005): Biology and natural enemies of Tetranychus urtica in sweet pepper. Manejo Integrado de Plagasy Agroecologia. Centro Agronomico Tropical de Investigacion Ensenanza, Turrialba, Costa Rica, 74:34-40.

Gendy, A.S.H. and Nosir, W.S. (2016). Improving productivity and chemical constituents of Roselle plant (Hibiscus sabdariffa L.) as affected by phenylalanine, L- tryptophan and peptone 
acids foliar application. Middle East Journal of Agriculture, 5(4):701-708.

Gomaa, A.O. (2003). Effect of foliar application with some amino acids and vitamins on growth, flowering and chemical constituents of Crinum asiaticum plants. Egypt. J. Appl. Sci., 18(6B):736-754.

Gomez, K.A. and Gomez, A. A. (1984). Statistical Procedures for Agricultural Research. John Wiley \& Sons Inc., Singapore, $680 \mathrm{p}$.

Goss, J.A. (1973). Amino acid synthesis and metabolism. In Physiology of Plants and Their Cells. Pergamon Press, Inc., New York, 202 p.

Guenther, E. (1961). The Essential Oil D. Van Nostrand Comp., New York, 1: 236.

Hussein, M.H. (1982). Population density of destructive and beneficial insects on some medicinal and aromatic plants. Assuit J. Agric. Sci., 13:165-172.

Hussein, M.H. and Abd EL-Aal, S.A. (1982). Wild and honey bee as pollinators of 10 plant species in Assiut area. Egypt. Z. ang. Ent., 93:342-346.

Ibrahim, M.H.; Jaafar, H.Z.; Rahmat, A. and Rahman, Z.A. (2011). Effects of nitrogen fertilization on synthesis of primary and secondary metabolites in three varieties of Kacip Fatimah (Labisia pumila Blume). International Journal of Molecular Sciences, 12(8):5238-5254.

Ismail, H.A.; Kelany, I.M.; Abd EL-Megid, J.E. and Ibraheem, M.M.A. (2010). Survey and relative densities of insect pests and their predators associated with mint, roselle and marjoram at Abo-Kabir district Sharkia Governorate. Zagazig J. Agric. Res., 37(5):1193- 1210.

Jain, P.C. and Yadav, C.P.S. (1989). Incidence of pests and their control on coriander. Indian Cocoa Arecanut Spices J., 13(2):61-62.

Janmohammadi, M.; Sufi-Mahmoudi, Z.; Ahadnezhad, A.; Yousefzadeh, S. and
Sabaghnia, N. (2014). Influence of chemical and organic fertilizer on growth, yield and essential oil of dragonhead (Dracocephalum moldavica L.) plant. Acta Agriculturae Slovenica, 103(1):73-81.

Marschner, H. (1995). Minerals of Higher Plants, $2^{\text {nd }}$ Ed. New York, Academic Press, 889 p.

Meena, R.S.; Gupta, H.C.L.; Sharma, R.P. (2011). Estimation of losses by coriander aphid. Ann. Plant Protect. Sci., 19(1):226-227.

Mendes, H.M.; Resende, A.L.S.; da Silva, V.F.; Souza, B.; Cláudio, L. and Silveira, P. (2015). Parasitoids of horticultural pests associated to commercial developmental stages of cultivated Apiaceae. Entomotropica, 30(17):174180.

Meyer, B. S.; Anderson, D. B. and Bohning, R. H. (1968). Introduction to Plant Physiology. D. Van Nostrand Company, New York, USA, p 179-189.

Mhemdi, H.; Rodier, E.; Kechaou, N. and Fages, J. (2011). A supercritical tunable process for the selective extraction of fats and essential oil from coriander seeds. J. Food Eng., 105 (4):609-616.

Nadeem, M.; Anjum, F.M.; Khan, M.I.; Tehseen, S.; El-Ghorab, A. and Sultan, J.I. (2013). Nutritional and medicinal aspects of coriander (Coriandrum sativum L.). A review. Brit. Food. J., 115(5):743-755.

Omer, E.A.; Said-Al Ahl, H.A.H.; El Gendy, A.G.; Shaban, Kh.A. and Hussein, M.S. (2013). Effect of amino acids application on production, volatile oil and chemical composition of chamomile cultivated in saline soil at Sinai. J. Appl. Sci. Res., 9(4):3006-3021.

Pons, X. and Lumbierres, B. (2004). Aphids on ornamental shrubs and trees in an urban area of the Catalan coast: bases foe an IPM program. Aphids in a new millennium Proceedings of the Six 


\section{E.A.M. El-Mogy et al.}

International Symposium on Aphids 2001, pp. 359-364.

Rashad, S.E. (1976). Experience with pollination of tropical crops. Apiculture in tropical climate, London, pp. 109-112.

Rashad, S.E. (1978). Utilization of non Apis bees as crop pollinators. EG. ARS., 66:48.

Salem, A.A.A.; Ali, A.G.; Azab, Samiha G.; Mohamed, Doaa S. and Mahmoud, Omima S. (2016). Relative abundance of the major piercing-sucking pests and their associated natural enemies on coriander plants (Coriandrum sativum L.) in Assiut Governorate. Ass. Univ. Bull. Environ. Res., 19(1):17-35.

Swami, D.; Jat, B.L. and Dotasara, S.K. (2018). Population dynamics of insect pests of coriander and their correlation with biotic and abiotic factors. J. Ent. and Zool Studies, 6(4):460-464.
Talaat, I.M. and Youssef, A.A. (2002). The role of the amino acids lysine and ornithine in growth and chemical constituents of basil plants. Egyptian J. Appl. Sci., 17:83-95.

Upadhyay, S.; Mishra, R.C. and Nigam, K.B. (1996). Magnitude of damage and assessment of losses in yield of coriander genotypes by Hyadaphis coriandari Das. J. Insect Sci., 9(2):168-169.

Vopyan, V.G. (1984). Agricultural chemistry. Leat By B. A. Jvage Din, B. Sc. Translated From the Russian by V. S. Vopyan $1^{\text {st }}$ Publishers, Moscow.

Walter, G.R. and Nawacki, E. (1978). Alkaloid Biology and Metabolism in Plants. Planum, Press, N.Y; 152 p.

Wangensteen, H.; Samuelsen, A.B. and Malterud, K.E. (2004). Antioxidant activity in extracts from coriander. Food Chem., 88:293-297.

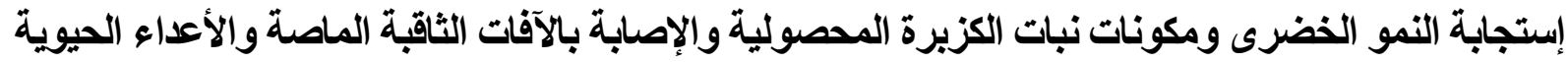

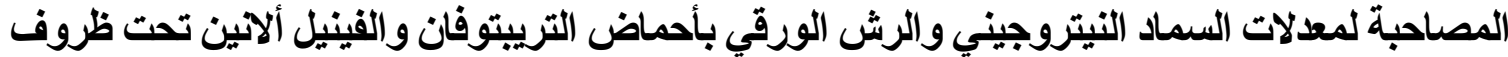 الأراضي ألرملية}

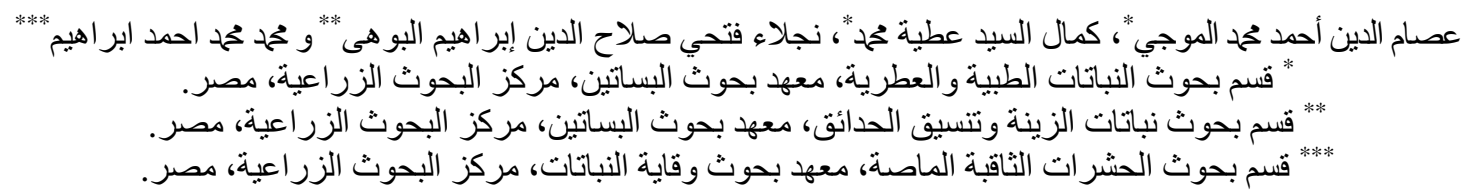

تم إجراء هذ الدراسة في المزرعة التجريبية لمحطة البحوث الزراعية بالقصاصين بمحافظة الإسماعيلية بمصر

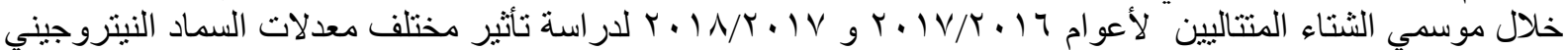

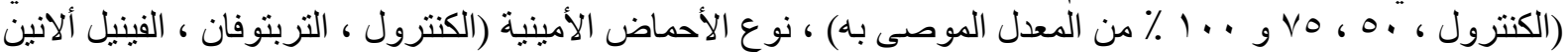

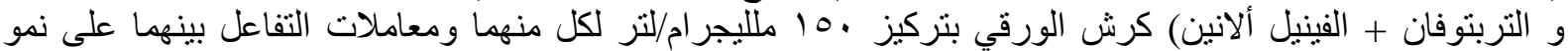

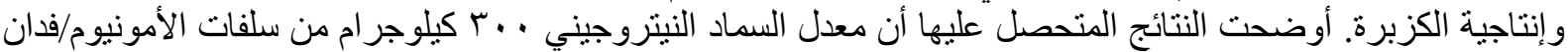

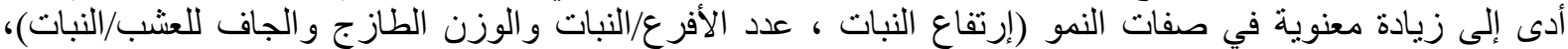

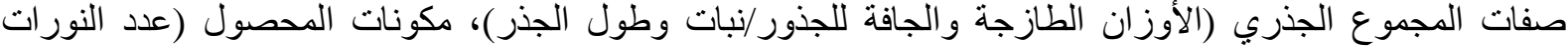

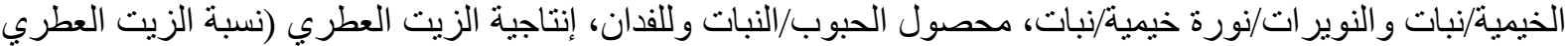

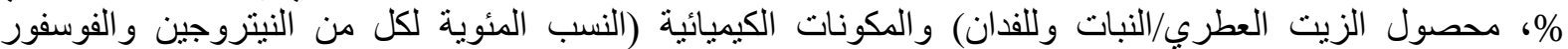

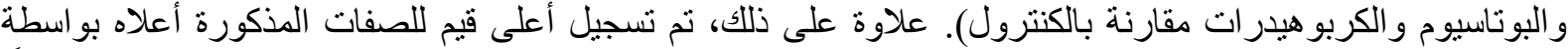

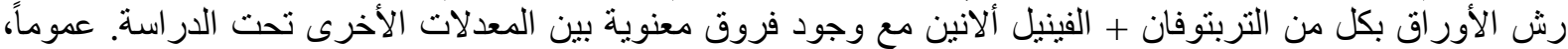

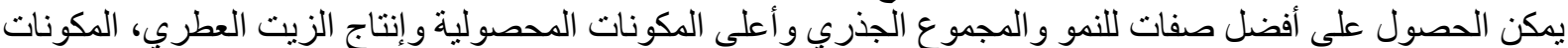

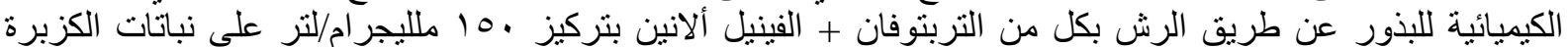
المسمدة بالمعدل الموصى به من النيتروجين. 


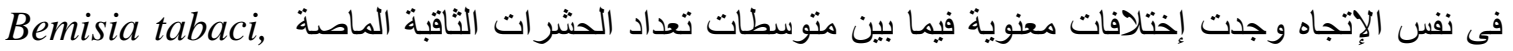
Hyadaphis coriandri, Tetranychus urticea and Thrips tabaci

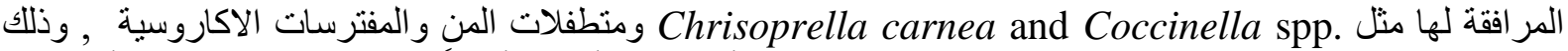

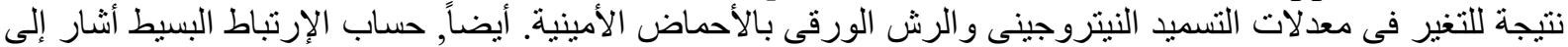

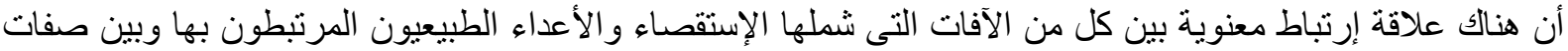
النمو (إرتفاع النبات و عدد الأفرع/نبات بنات). 